[методична розробка] / Е. Лавут. - Сімферополь : Мала академія наук Криму «Пошукач», 2009. - 31 с. 3. Пришляк М. П. Астрономія : [підручник для 11 класу загальноосвітніх навчальних закладів] / М. П. Пришляк. - Харків : Ранок, 2003. - 144 с.

\title{
ПОНЯТТЯ «КРЕАТИВНІСТЬ»У СИСТЕМІ ПІДГОТОВКИ МАЙБУТНІХ ЕКОНОМІСТІВ В УМОВАХ ВНЗ
}

У статті зроблено спробу розкрити зміст поняття «креативність» $у$ системі підготовки майбутніх економістів в умовах вищих навчальних закладів. Обтрунтовано взаємозалежність розвитку креативного компонента особистісного утворення майбутніх фахівців економічного профілю зі створення креативного навчального середовища.

Ключові слова: креативність, креативні якості, майбутні економісти, BH3.

В статье сделана попьтка раскрыть сущуность понятия «креативность» в системе подготовки будущих экономистов в условиях высших учебных заведений. Обоснована взаимосвязь развития креативного компонента личностного образования будущих профессионалов экономического профиля по образованию креативного учебной среды.

Ключевые слова: креативность, креативные качества, будущуие экономистьи, вуз.

The article attempts to uncover the essence of the concept of "creativity» in the training of future economists in higher education. Proved the relationship of the creative component of the personal education of future professionals in economics education creative learning environment.

Key words: creativity, creative quality, future economists, university.

Головною метою вищої освіти $є$ формування фахівця нової формації, здатного працювати в постійно змінюваних умовах й орієнтованого на творчу професійну діяльність. Нині функції вищої школи постійно ускладнюються, що пояснюється необхідністю швидкого реагування на попит ринку праці, гнучкості керування, адміністративногосподарської самостійності тощо.

Традиційно науковці критерієм творчих пошуків називали виготовлення потрібного нового продукту (Й. Гердер, 
Р. Вайсберг). Необхідність і значущість для соціального оточення визначила напрями дослідження змісту творчої професійної діяльності в педагогічних розвідках. Соціокультурний аспект поняття креативності закцентовано С. Бондаревською, С. Бурцевою, С. Лаврухіною, І. Макарцевою; культуротворчість як усвідомлене входження в культуру професійного співтовариства й участь у колективному формуванні фахових смислів вивчали Ю. Куницька, Т. Бабкіна; різноманітні аспекти креативності за спільного підходу до їх зумовленості соціальною природою індивіда розробляли Л. Колмогорова, В. Кудрявцев, Г. Уразалієва, А. Майєр та ін.

Останнім часом поняття креативності увійшло в дослідження вітчизняних науковців як аспект культурної діяльності і складова професійної культурологічної підготовки (І. Зязюн, Л. Кондрацька, О. Рудницька, О. Шевнюк та ін.). Наукові розвідки, у яких безпосередньо розкрито природу, системи, процеси творчої діяльності як своєрідної культуротворчості й охарактеризовано освіту як іiї феномен, грунтовно розкрито вітчизняним філософом В. Леонтьєвою. Професійна творча діяльність визначається нею як створення культури в межах професійної діяльності.

Значущість сформульованої проблеми підтверджується багатьма державними актами, європейськими програмами i постановами (Закон України про вищу освіту, Велика університетська хартія). На підставі вивчення кардинальних світових тенденцій у галузі праці, аналізу ключових проблем у сфері підготовки кадрів економічного профілю, зарубіжної практики, узагальнення вітчизняного прогресивного педагогічного досвіду виявлено професійно-педагогічні суперечності: 1) між становленням виробничої парадигми, яка заснована на креативності, і недостатнім представленням цієї тенденції в концепціях професійної підготовки; 2) між цілісним системним характером процесу створення нового у професійній діяльності і дискретним уявленням про нього в майбутніх фахівців економічного профілю; 3) між виробничими вимогами дотримання фахівцем існуючих правил і фрагментарною репрезентацією їх у професійній освіті щодо досвіду ix перетворення 3 метою оновлення кодифікованих смислів і готовністю майбутнього фахівця до реакції соціального середовища на процес креативного перетворення соціокультурної дійсності. 
Mema cmammi: розкрити зміст поняття «креативність»у системі підготовки майбутніх економістів в умовах ВН3 3 урахуванням нової виробничої парадигми - творчої праці.

Випускники вищої економічної школи мають бути готовими до визначення стратегії керівництва, сполучення адміністративно-демократичних начал і централізації керування, консолідації особистісного й професійного потенціалу в розв'язанні завдань на етапі самостійної професійної діяльності.

Вимога сучасної модернізованої якісної освіти в економічній вищій школі відводить окрему роль стандарту професійного образу майбутніх випускників і ступеня їхньої готовності до виконання професійних функцій. Критеріями економічної освіти є параметри особистісного розвитку майбутніх економістів, серед яких особливо значущою характеристикою $є$ креативність.

Ефективність виконання професійних функцій визначається тим, наскільки сучасний фахівець готовий до творчої професійної діяльності. Багато прорахунків у практичній роботі пов'язані зі стереотипністю мислення людини, що суттево гальмує процес творчої професійної діяльності.

Професійна підготовка до культуротворчості повинна враховувати, що створення нового - це складний соціокультурний процес, результати якого, перш за все, позначаються на долі середовища виникнення новації і намагання іï впровадження. Сукупність чинників визначає властивості соціокультурного середовища як сфери дій малих груп і особистості [5; 6].

Грунтовний аналіз сучасних механізмів урегулювання наслідків створення і впровадження нового на державному, міжнародному, європейському рівнях дозволив зробити висновок про те, що в сучасній вищій економічній освіті [5; 6; 8]:

- невідкоригований вплив однієї культури на іншу викликає невідповідності під час обміну передовим педагогічним (підготовка кадрів економічного профілю) та економічним (досвід перетворювальної професійної діяльності економістів) досвідом;

- соціальному середовищу надано право на обмеження творчості відповідно до нових стандартів полікультурного світу, місцевих і регіональних традицій, тенденцій глобалізації і всесвітніх процесів інтеграції у сфері економіки; 
- рівновага інтересів індивіда і соціального середовища реалізується через принципи пропорційності, справедливості, паритетності, толерантності, а інтереси більшості, які потребують скорочення виборів для дій індивіда, є визначальними при винесенні рішення про доцільність його професійних дій.

Наведені вище міркування актуалізують розгляд сутності творчої особистості, спрямованої на перетворення соціокультурної дійсності. У ракурсі нашого дослідження цінними $\epsilon$ розвідки Ю. Бабанського, Д. Богоявленської, О. Ісмаїлової, які теоретично обгрунтували поняття «творча особистість», виходячи 3 того, що творча особистість має високий рівень інтелекту, різнобічні знання, потребу в новизні, здатність до оригінальність дій, до нейтралізації стереотипних дій у професійній поведінці. Безумовно, більш детально й грунтовно досліджено специфічні особливості творчої особистості, шляхи й способи розвитку її творчих здібностей.

У контексті підготовки майбутніх економістів результативність навчання у формуванні професійного образу економіста можлива за наявності ціннісної орієнтації студента й креативної спрямованості установок його професійних дій. Перелік професійно значущих якостей сучасного економіста нині доповнюють креативністю і здатністю до інноваційної діяльності. Виходячи $з$ природи економічної праці, можна стверджувати, що креативність $є$ важливим складником професійного стандарту економіста.

Поняття «креативність» було в полі посиленої уваги вітчизняних і зарубіжних науковців. Цінними для нас $є$ розвідки психолога В. Дружиніна, який розглядає креативність як загальну здатність особистості до творчості й уважає, що вона виявляється в різних формах активності [7, с. 351].

Розширює наші уявлення про креативність В. Сластьонін, який цією якістю називає здатність, яка забезпечує людині можливість створювати оригінальні цінності й приймати нестандартні рішення $[11$, с. 18$]$. На його думку, саме ця якість дозволяє особистості виявляти свою неординарність, обдарованість при розв'язанні різних завдань.

В аспектуальному ракурсі досліджували креативність Л. Алексєєва [2] й О. Виноградов [3], які виокремили кілька аспектів: 1) предметно-процесуальний і рефлексивний (процес розв'язання творчих завдань); 2) особистісний (особливості креативної особистості); 3) продуктивно-результативний і соціально-управлінський (умови креативного розвитку осо- 
бистості, iї самовираження й опосередкованого керування процесом співтворчості в навчанні). Учені розглядають креативність як комплекс інтелектуальних та особистісних особливостей індивіда, що доводить слушність твердження вчених про креативність як складне особистісне утворення, що сприяє самостійному висуванню проблем, генеруванню значної кількості оригінальних ідей і нешаблонному їхньому розв'язанню.

Наведені вище міркування переконують у тому, що креативність варто розглядати як характеристику взаємопов'язаних інтелектуальних та особистісних особливостей індивіда, від виразності яких залежить успіх його творчої діяльності. Креативність визначає здатність особистості створювати нове знання, нові способи розв'язання проблем, відходити від штампів, звичних суджень, формальних рішень. Нестандартність, незвичайність, новизна в діях особистості визначаються іiї якостями та внутрішньою мотивацією.

Креативність трактується найбільш широко з позиції функціонально-діяльнісного підходу (вияв пошуковоперетворювальної активності (В. Козленко); інтелектуальна активність, що домінує над стимулом і здійснюється за межами, визначеними завданням (Д. Богоявленська); творча здібність (В. Дружинін); як одна з провідних рис інтегративного характеру, що виявляється на різних рівнях: психофізіологічному в механізмах регуляції (П. Анохін); орієнтувально-пристосувальному в механізмах установки (Д. Богоявленська), пізнавально-перетворювальному в механізмах цілевизначення (О. Тихомиров).

Розвиваючись у діяльності й будучи представленою в структурі особистості, креативність виражає здатність до продуктивних перетворень, створення якісно нового.

Тісний взаємозв'язок вияву креативності і перебігу когнітивних процесів у структурі креативної особистості дозволяє виокремити визначальні характеристики креативності: конструктивна активність і вербальна креативність, характериситики найбільше відповідають вимогам, що висуваються до особистості економіста. У конструктивній активності виявляються операційні властивості візуального мислення, пов’язані зі ступенем складності та варіативністю перетворень набутої інформації. Процеси, що відбуваються у сфері креативного мислення, є основою конструктивної уяви. Конструктивна активність трактується як здатність особистості 
до трансформації вихідної перцептивної опори. Вербальна креативність визначається як процес перекодування елементів ситуації, пов'язаний зі здатністю переборювати стереотипи й здійснювати розумовий пошук у семантичному полі, створюючи нові асоціації за змістом. Величина віддаленості асоціації від стереотипу є показником креативності.

У суб'єктивній позиції виявляється значущість «Я» студента, його особистісний і професійний плани, їхня співвіднесеність. У процесах власної активності студент виявляє особистісні можливості, креативні здатності й стимулює власний професійний ріст. Отже, креативність, як складне особистісне утворення, виконує функції індивідуальнотворчого розвитку студентів, що уможливлює пристосування креативних якостей до пізнавальних ситуацій, а також до власних індивідуально-психологічних особливостей i професійних смислів.

Креативність як складне особистісне утворення, де особистісні здатності особливим чином взаємодіють 3 пізнавальними потребами й інтелектуальною діяльністю, характеризується такими ознаками: активно спонукальне виконання навчально-пізнавальних завдань; винахідливість, нестандартність при розв'язанні навчальних проблем; уміння перероблювати навчальну інформацію шляхом аналізу, синтезу, аналогії, індукції, дедукції й узагальнення; аргументувати власну позицію, вступаючи до дискусії (диспуту, навчального діалогу) під час розв'язання навчальних завдань.

Розвиток креативності, як складного особистісного утворення, у якому професійно-особистісні особливості майбутнього фахівця найбільшою мірою взаємодіють 3 пізнавальними потребами й когнітивною діяльністю при організації особистісно-розвивального навчання.

Особистісно-розвивальне навчання на відміну від традиційного містить у собі умови для розвитку здатності до продукування нових ідей, готовності до нестандартних ситуацій і нестереотипної поведінки студентів у навчальних ситуаціях. Нові вимоги до професійного образу майбутнього економіста передбачають нові підходи й принципи підготовки їх в умовах економічної освіти. Новизна підходу в підготовці сучасних кадрів полягає в тому, щоб забезпечити таку дидактичну реальність, у якій майбутні фахівці опановували б особистісно-креативні функції з урахуванням динамічного еко- 
номічного простору відповідно до тенденцій розвитку глобалізованої світової економіки.

3 огляду на те, що модернізація вищої економічної освіти переслідує мету формування творчої індивідуальності, готової працювати в оновлених умовах, здатної розробляти, освоювати й використовувати інноваційні проекти, до психологічної структури діяльності фахівця й моделі його підготовки до традиційно визначених когнітивного, організаторського, комунікативного, інформаційно-перетворювального слід включити й «креативний як базовий, системоутворювальний, який інтегрує всі інші компоненти на якісно новому й оперативно довершеному рівні» [1, с. 107].

Створення нового у професійній діяльності порушує проблему рівня оновлення професійних смислів та ї результативності, що може позначитися на значній кількості фахівців у сфері економіки, водночас може стати актуальним в обмеженому виробничому колективі. Тому важливо виокремити ознаки, за якими розмежовують і рівні, і результати виникнення нового, креативного продукту. Виробничі вимоги передбачають нове відповідно до сформульованих бажаних характеристик. Наскільки створення на «замовлення» $\epsilon$ творчістю, можна зрозуміти за атрибутами отриманого продукту. Так, оформлення нового продукту в чітких і визначених параметрах інтерпретовано як ознаку чогось іншого, ніж високе мистецтво.

Такий висновок аргументується результатами аналізу великої кількості автобіографічних матеріалів видатних відкривачів, науковців, митців. Вони свідчать про те, що задумів завжди набагато більше, ніж створеного реально. Це тлумачиться як внутрішній образ, який не втілено у форму, оскільки втілення у форму, завершеність, доведення до кінця - це ознаки творів (продуктів) нижчого рівня, все це - результат звички, досвіду, специфічного таланту [8; 10, с. 298 -299].

Різні рівні створення нового - вищий, що супроводжується особливими емоційними, інтелектуальними станами, i нижчий, який потребує досвіду створення нового як навички - виявляють різні результати у професійній економічній діяльності. Безумовно, професійна підготовка до створення нового повинна враховувати різні рівні перетворювальної активності індивіда. Індивідуальне прагнення змін і колективний сталий розвиток детермінуються витоками нескінченного творчого потенціалу. культурна традиція, які і забез- 
печують сталість на відміну індивідуальному прагненню змін [8, c. 84-87].

Самовираження $є$ необхідністю, а усвідомлення цього людиною важливим моментом, оскільки індивідуальне існування - це реалізація сукупності альтернатив. Отже, створення нового у професійній сфері - це вільне й усвідомлене волевиявлення [7].

Професійна підготовка майбутніх економістів має враховувати новітні тенденції розвитку соціокультурної дійсності, відповідно забезпечувати організацію навчання з урахуванням вимог до сучасного фахівця, що у свою чергу передбачає ефективне упровадження професійно орієнтованих технологій. Створення креативного навчального середовища, зорієнтованого на засвоєння знань, креативне навчання, інтенсифікує набуття нового знання, оволодіння вмінь і навичок нестандартної діяльності, досвіду креативних дій у сфері професійної діяльності економіста.

Процес навчання набуває нового сенсу й нового досвіду діяльності майбутніх економістів. Розвиток креативного компонента підготовки майбутніх економістів, обгрунтований у дослідженні, досягається шляхом організації навчальної діяльності майбутніх економістів, зорієнтованої на створення й використання новітніх способів, форм і технологій навчання, основу яких складає креативна діяльність.

Подальшого вивчення потребує питання складових якостей креативного компонента особистісного утворення майбутніх економістів.

\section{Література}

1. Абасов 3. Подготовка к инновационной педагогической деятельности / 3. Абасов // Педагогика. - 2002. - № 3. - С. 106-108. 2. Алексеева Л. Н. Рефлексия как средство творческого понимания: автореф. дис. на соискание ученой степени канд. психол. наук: спец. 19.00.07 «Общая психология»/ Л. Н. Алексеева. - М., 1988. - 24 с. 3. Виноградов А. Г. Проявление творческой интеллектуальной активности в связи с особенностями организации понятийного знания : автореф. дисс. на соискание ученой степени канд. психол. наук: 13.00.07 «Общая психология» / Александр Геннадьевич Виноградов. - Киев, 1990. - 23 с. 4. Выготский Л. С. Воображение и творчество в детском возрасте / Л. С. Выготский; А. Н. Драчев (ред.). - СПб. : Союз, 1997. - 96 с. 5. Высшее образование в XXI веке: подходы и практические меры: Рабочие доклады (5-9 октября 1998 г.). - Париж: ЮНЕСКО, 1998. - 90 с. 6. Державна національна програма «Освіта» (Україна 
XXI століття) // Науково-освітній потенціал нації: погляд у XXI століття / упоряд. Литвин В., Андрущенко В., Гуржій А. та ін. - К. : Навч. книга, 2004. - Кн. 3: Модернізація освіти. - К., 2004. - С. 243- 270. 7. Дружинин В. Н. Психология общих способностей / Владимир Николаевич Дружинин. - СПб. : Питер, 1999. 368 с. [Серия «Мастера психологии»]. 8. Свропейська конвенція 3 прав людини / Рада Європи / Олександр Павличенко (відп. ред.) ; [пер. Є. М. Вишневського]. - К. : Українська правнича фундація, Б. p. - 38 с. 9. Ермолаева-Томина Л. Б. Опыт экспериментального изучения творческих способностей / Л. Б. Ермолаева-Томина // Вопросы психологии. - 1977. - № 4. - С. 74-84. 10. Марсель Г. Опыт конкретной философии / Г. Марсель ; пер. с фр. В. П. Большакова и В. П. Визгина ; общ. ред., послесл. и примеч. В. П. Визгина. - М. : Республика, 2004. - 224 с. 11. Педагогика : [учеб. пособ. для студ. пед. учеб. заведений] / В. А. Сластенин, И. Ф. Исаев, А. И. Мищенко, Е. Н. Шиянов. - М. : Школа-пресс, 1998. - 512 с. 12. Хайдеггер М. Бытие и время / М. Хайдеггер ; [пер. с нем. В. В. Бибихин]. - М. : Ad Marginem, 1997. - 452 с.

УДК 371.15:373.3

I. В. Онищенко, кандидат філол. наук, доцент, Криворізький педагогічний інститут ДВНЗ «Криворізький начіональний університет»

\section{ТЕОРЕТИКО-МЕТОДОЛОГІЧНІ ЗАСАДИ ФОРМУВАННЯ ПРОФЕСІЙНО-ПЕДАГОГІЧНОЇ КУЛЬТУРИ МАЙБУТНЬОГО ВЧИТЕЛЯ ПОЧАТКОВОЇ ШКОЛИ}

У статті визначено сутність професійно-педагогічної культури вчителя початкових класів, ї̈ структуру; обгрунтовано психолого-педагогічні умови та етапи технології формування професійно-педагогічної культури майбутнього вчителя початкової школи.

Ключові слова: професійна культура, професійно-педагогічна культура, вчитель початкових класів.

В статье определена сущность профессионально-педагогической культуры учителя начальных классов, ее структура; установлены психолого-педагогические условия и этапь технологии формирования профессионально-педагогической культуры учителя начальной школь.

Ключевые слова: профессиональная культура, профессиональнопедагогическая культура, учитель начальных классов.

The article explains the purpose of vocational and educational culture of primary school teacher, its structure, established psychological and pedagogical 